\title{
A Reconstructed Indigenous Religious Tradition in Latvia
}

\author{
Anita Stasulane $\mathbb{D}$
}

Faculty of Humanities, Daugavpils University, Daugavpils LV-5401, Latvia; anita.stasulane@du.lv

Received: 31 January 2019; Accepted: 11 March 2019; Published: 14 March 2019

\begin{abstract}
In the early 20th century, Dievturība, a reconstructed form of paganism, laid claim to the status of an indigenous religious tradition in Latvia. Having experienced various changes over the course of the century, Dievturiba has not disappeared from the Latvian cultural space and gained new manifestations with an increase in attempts to strengthen indigenous identity as a result of the pressures of globalization. This article provides a historical analytical overview about the conditions that have determined the reconstruction of the indigenous Latvian religious tradition in the early 20th century, how its form changed in the late 20th century and the types of new features it has acquired nowadays. The beginnings of the Dievturi movement show how dynamic the relationship has been between indigeneity and nationalism: indigenous, cultural and ethnic roots were put forward as the criteria of authenticity for reconstructed paganism, and they fitted in perfectly with nativist discourse, which is based on the conviction that a nation's ethnic composition must correspond with the state's titular nation. With the weakening of the Soviet regime, attempts emerged amongst folklore groups to revive ancient Latvian traditions, including religious rituals as well. Distancing itself from the folk tradition preservation movement, Dievturïba nowadays nonetheless strives to identify itself as a Latvian lifestyle movement and emphasizes that it represents an ethnic religion which is the people's spiritual foundation and a part of intangible cultural heritage. In the 21st century, Dievturizba is characterized by conflicting aspects: on the one hand, a desire is expressed to contrast itself and its ethnic views from globalization tendencies in its activities, but on the other hand New Age concepts and a self-reflexive character has entered its discourse.
\end{abstract}

Keywords: Dievturība; paganism; indigeneity; reconstructionist movement; nativism; nationalism

\section{Introduction}

The movement which has been described using various terms: paganism, neopaganism, contemporary paganism and revival paganism, encompasses "a collection of modern religious, spiritual, and magical traditions that are self-consciously inspired by the pre-Judaic, pre-Christian, and pre-Islamic belief systems of Europe, North Africa, and the near East" (Doyle White 2016, p. 6). It is a global movement without one single, unified, centralized teaching and organizing structure, which includes within it, the most diverse views and individual interpretations (Cf. Saunders 2013) and which is characterized by one common feature-the idealization of pre-Christian era religion. This article looks at a reconstructed form of paganism which developed in Latvia in the 1920s and continues to exist, expressing various constructions and stereotypes about "Latvian" myths, religion and culture.

In the early 20th century, Dievturizba ${ }^{1}$, a reconstructed form of paganism, laid a claim to the status of an indigenous religious tradition. Having experienced various changes over the course of the century,

1 Dievturība (Latvian)-'the Keepers of God'. An adherent of the movement is Dievturis (Latvian)-'God keeper', plural Dievturi. 
Dievturîba has still not disappeared from the Latvian cultural space, even though it has been unable to gain strength. As it has never been and, probably also never will be, a numerically broad movement, nowadays, Dievturizba is presented by the movement adherents, to be a way of life rather than a religion. As a result of the powerful pressure of globalization, attempts to strengthen indigenous identity have increased, and everybody who tries to preserve Latvian traditional craftsmanship, singing and dancing traditions, folklore etc., gets included within the Dievturïba.

The awareness of, and consolidation of Latvian identity becomes a significant factor in the circumstances of globalization. For almost fifty years, the Ethnographic Open-Air Museum of Latvia has been holding the traditional annual crafts market on the first weekend in June every year, with more than 36,000 people attending it in 2018 (Fotoreportāža 2018). This event has become a celebration of the Latvian lifestyle. The annual market is a place for meeting and exchanging professional experience for various generations and trades, makers of Latvian folk applied arts products from all regions of Latvia. Folklore groups, dance groups, bands, experts in ancient games and producers of traditional Latvian foods also take part in the festival. Therefore, everybody who maintains, creatively transforms or introduces today's society to the Latvian traditional culture.

The Latvian Ethnographic Open-Air Museum of Latvia is a place where Latvian traditional events are also celebrated: the winter solstice (Ziemassvētki), the summer solstice (Jāni), Martin's Day (Mārtindiena), the Eve of the Dead Souls (Velu vakars) etc. Folklore groups are the organizers of the events, but museum visitors also willingly participate in them. The authentic and indigenous is valued highly in Latvia, so one could imagine that this is good ground for the rebirth of the ancient Latvian traditional religion. Thus, on the one hand, we can observe attempts nowadays to reanimate archaic religious traditions and even construct sacred sites, but on the other hand, Dievturîba is still the interest of a group of enthusiasts who are small in number.

Dievturība is characterized by contrasting aspects in the 21st century: on the one hand, it is presented as an authentic component of Latvian culture, but on the other hand, non-local (mainly New Age) sources are used for it to transform from theoretical teachings into a living religion. Another contradiction is expressed in the context of globalization: the reconstructed Latvian religious tradition is attempting to adapt to an increasingly multicultural society, emphasizing that it is not a religion, but a way of life. This is a striking example of how contemporary paganism is striving to breach narrow ethnic boundaries, absorbing other ethnicities living in Latvia.

In this article, we will review the conditions which have determined the reconstruction of the indigenous religious tradition in the early 20th century, what sorts of forms it initially gained and how these changed over the course of history. The issue of the sources which were used in reconstructing the Latvian traditional religion will remain untouched. Well known Baltic religious researcher Haralds Biezais (1906-1995), whose most important work has been dedicated to the archaic Latvian religion (Biezais 1955, 1961, 1972), has undertaken research on this aspect. In evaluating folk songs as a source of information on the ancient Latvian religion, he has come to the conclusion that research on Latvian mythology in the early 20th century was undertaken without a defined methodology and folk songs were used uncritically. This criticism was focussed first of all on the founders of Dievturiba, as it was them specifically who tried to find Latvian archaic religious elements in folklore. ${ }^{2}$

\section{Between Indigeneity and Nationalism}

The Dievturi ${ }^{3}$ movement began in the 1920s not long after the creation of the Republic of Latvia (1918), when, with the collapse of the Russian Tsarist Empire, the Latvians also finally gained political power. Up until 1918, Latvia was part of Tsarist Russia, moreover, it was administratively divided: the

2 For more about the development of research on religion in Latvia, see (Priede 2015).

3 It is significant that not all actors described by social researchers as pagans, neo-pagans or contemporary pagans would necessarily call themselves pagans etc., and this is particularly the case in Latvia. 
Courland Governorate existed in the west and the Livonian Governorate in the central part where political power belonged to the Baltic-Germans, while the eastern part of Latvia, which fell within the Vitebsk Governorate (currently Byelorussia), was dominated by the Poles. The administrative disunity was the main hurdle on the road to the takeover of political power by the Latvians. It was for this reason specifically, that the unification of the various territories inhabited by the Latvians became the central idea in the creation of the new state. The slogan United for Latvia was the foundation on which the new democratic republic was built. The Latgale ${ }^{4}$ liberation monument Vienoti Latvijai (United for Latvia), known as Latgale's Māra, ${ }^{5}$ which has a young woman in a traditional Latvian costume with a cross held high in her right hand, and was erected in the eastern Latvian city of Rēzekne, was evidence of its importance and long-term urgency. Several symbolic levels flow together in this image: the mythical, the religious and the political, but its central message is the unification of the Latvians.

To understand the socio-political context in which the Dievturi movement came about, one should take into account that Latvia was a markedly multi-ethnic and multi-denominational country at the time that the nation was created. For example, there were $54.89 \%$ Latvians, $15.75 \%$ Germans, $13.63 \%$ Jews, $6.68 \%$ Russians, and $4.33 \%$ Polish and other ethnicities among the residents of Riga in 1920 (Švābe et al. 1933, p. 20442). The religious landscape was just as diverse: $57.29 \%$ Lutherans, 23.51\% Catholics, $8.7 \%$ Orthodox, 4.99 Jews, $4.59 \%$ Old Believers et al. The situation in politics was even more complex, where the need to create consensus was particularly important, as 46 candidate lists had gained mandates in the Republic of Latvia's parliament's (Saeima) first elections (1922) (Latvijas Republikas Saeima). This kind of socio-political division threatened attempts to put unity into practice, while it created the pre-conditions to search for new solutions, and not just in the administrative political sphere, but also on issues which affected the interests of the various ethnic and religious communities.

In this context, the Dievturiza movement was one of the proposals for solving the important socio-political issues of the time. Researcher Agita Misāne considers that "Dievturība is the religious answer to questions about the place of ethnic Latvians in the Latvian nation, the character of Latvian identity and its religious dimension in particular, the titular nation's responsibility for processes taking place in the country, the state's relationships with religious organizations, the attitude of Latvians to minorities and relationships with them, and the possibility of formalizing and legitimizing the aggregate of all of these relationships not just on the political but also the religious level" (author's translation) (Misāne 2005, p. 101). The activities of the Dievturi were interwoven with the idea of a special mission-to unite the Latvians, putting forward indigenous religious values as the unifying element.

Even though there were attempts to make Christianity more Latvian, they were destined for failure. The desire to make a radical change-to return to pre-Christian religion-was determined by the collapse in the authority of the Church at that time. In the early 20th century, Christianity in Latvia was weak, not just because of the denominational divisions, but also due to the special socio-political conditions. The Evangelical Lutheran Church which dominated in most parts of the country was perceived as a bulwark of the Tsarist system, and in the light of the 1905 revolution, it appeared to be a reactionary institution. The Latvian Evangelical Lutheran Church's position was against the social changes proposed by revolutionaries, as a result of which Lutheran priests (especially the Baltic Germans) gained an image as being enemies of the people. Christianity was the treated as a religion, which had been forced onto the Latvians by fire and sword. It should be added that representatives of the Latvian Evangelical Lutheran Church, in particular, were the most active opponents of Dievturiba, and also took a very strong position against the strategic goal of the Dievturi-to achieve the recognition of the reconstructed Latvian religion as the state religion.

4 Latgale is the eastern part of Latvia which was a part of the Vitebsk Governorate till 1918.

5 Sculptor K. Jansons, design by L. Tomašickis. As the monument was dedicated to the liberation of Latgale from the bolsheviks (1939), it was destroyed twice (1940 and 1950) by communists and renewed twice (1943 and 1992). 
The intellectual atmosphere of the time should also be taken into account. A narrative about an enslaved and long-suffering people was born as it was necessary to substantiate the right of the Latvians to create their nation: the Latvians lost their independence in the 13th century, were Christened by fire and sword and ended up under the German yoke for 700 years. Fitting in with the intellectual atmosphere of their time, historians began to unequivocally interpret the spread of Christianity in the territory of Latvia as an expression of colonial policy, its instrument being religion, respectively, Christianity. This interpretation turned out to be so sustainable that it was still repeated in encyclopaedias published by exile Latvians in the mid-20th century. ${ }^{6}$

In 1925, Ernests Brastinš (1892-1942) and Kārlis Marovskis-Bergžis (1885-1958) published a small brochure Latviešu dievturības atjaunojums (The Renewal of Latvian Dievturība) (Brastinš and Bregžis 1925), which appealed for the renewal of the ancient Latvian religion. The Latviešu Dievturu Sadraudze (Community of Latvian Dievturi) was registered in 1926 as a religious organization, but experienced internal division soon enough. Brastiňs' confrere Marovskis-Bergžis (1885-1958) did not hold out hope that Dievturizba could become the religion of all of the Latvian people. In his view, the religion of the ancient Latvians was for worship within the family and in small groups. In contrast, Brastinšs, as befitting a graduate of the St.Petersburg Military College, had great ambitions, including political ones. If Marovskis-Bergžis consistently objected to the involvement of Dievturi in politics, then Brastinšs searched for opportunities to strengthen Dievturïba with political instruments as well.

One could expect that Brastinš was operating in a favourable political situation for the Dievturi, especially after Kārlis Ulmanis' (1877-1942) coup, as his authoritarian regime (1934-1940) emphasized Latvian traditional values and tried to create a Latvian Latvia. However, Dievturība was unable to reinforce its position, as Ulmanis gave preference to the Evangelical Lutheran Church, which turned against the Dievturi. Searching for allies in politics, the Dievturi leaders established contacts with the Pèrkonkrusts (Thunder Cross) organization, which propagated the ideology of Latvian nationalism. Brastinš, who emphasized the special historical and religious mission of the Latvian people, found common ground with the Perrkonkrusts group, ${ }^{7}$ and their collaboration strongly illustrates the tendency of religious nationalism to gain political influence in pre-war Latvia.

Brastiňš' ideal was Naciokrātisms (Natiocracy) (Brastinš 1936, p. 248), respectively, a theocratic state, where political power would be concentrated in the hands of one religious leader (Brastinš 1929, p. 11). His political programme included a plan for allocating the right to vote only to Latvians and to get rid of the influence of ethnic minorities in Latvia (Brastinš 1935, p. 92). In this way, the Dievturi political programme corresponded completely with the basic principles of the radical right-wing Pērkonkrusts political organization. Moreover, the ideologues of both organizations were united not only by the slogan Latvia for Latvians, the turning against ethnic minorities in Latvia (particularly Jews and Baltic Germans), dissatisfaction with the Ulmanis regime, but also criticism of left-wing political parties. ${ }^{8}$

Even though the view prevails that Perkonkrusts merely took advantage of the Dievturi, maintaining the secular character of their own organization, it should be pointed out that individual members of the Perrkonkrusts group were members of the Dievturi community. It is significant that Brastinš was the generator of the Pérkonkrusts group's name. ${ }^{9}$ Even though it is not clear which organization, the Dievturi or Pērkonkrusts, were the initiators of the collaboration, it is obvious, that they were brought closer together by Ulmanis' coup (15 May 1934). It can even be confirmed that up

6 See the entry about the oldest chronicle of Latvia's and Estonia's history, Heinrici Chronicon, in the encyclopedia produced under historian Arveds Švābe's editorship: "the history of salvation, which took place by fire and sword" (Švābe 1950, p. 798).

7 Brastinš was already a member of the Pērkonkrusts group in 1933. (Cf. Paeglis 2005, pp. 10-11, 129).

8 The collaboration between Dievturi and Pêrkonkrusts is analysed in more depth in an earlier publication (Cf. Stasulane 2013a, pp. 31-46).

9 On 12 April 1932, the Ugunskrusts (Fire Cross) organization was closed down, but on 12th May it was reregistered with a different name-Pērkonkrusts. 
until the coup, it was mainly the Dievturi, whose numbers did not even reach a thousand, that were mainly interested in collaborating. They hoped that they could become more than a marginal religious movement through collaboration with Pèrkonkrusts. However, after the coup, when Pèrkonkrusts was forced to operate illegally, collaboration became vitally important for Perkonkrusts members as well, who came together for meetings at Dievturi buildings.

The beginnings of the Dievturi movement and its history up until the Second World War was a striking reminder of how dynamic and fruitful the relationship was between indigeneity and nationalism. The indigenous, cultural and ethnic roots of Dievturība were selected as the criteria for the authenticity of reconstructed paganism, and they fitted into nativist discourse perfectly, which is based on the conviction that the ethnic composition of a nation should correspond with the state's titular nation. Even though nativism cannot be equated with racism because nativism is centred in ethnopluralism which stresses the equality but incompatibility of different ethnicities living together (Cf. Rydgren 2005), it has still had its role in the development of extreme forms of nationalism (Italian Fascism and German National Socialism). Nowadays too, nativism, which is still the central element of right-wing political discourse, sustains the conviction that a nation has to be congruent with the titular nation. In sum, nativism with its exclusionist ideology, as a form of cultural racism, insists on the preferential treatment of locals (natives) in protecting their culture.

\section{Dievturība as a Reconstructionist Movement}

Following the usual contemporary classification of paganism (Cf. Davy 2007), the existing form of paganism in Latvia, Dievturība, can be classified as a reconstructionist movement, which emphasizes in particular the importance of historical passing down and searches for evidence of ancient Latvian religion in folk traditions, folklore, archaeology etc. It is particularly significant that Dievturība has never been a numerically broad movement, ${ }^{10}$ and it could sooner be considered as an intellectual movement. In addition to Brastinš, who was mentioned previously, the most active representatives of Dievturi in the 1920s and 1930s were painter Jēkabs Bīne (1895-1955), writers Voldemārs Dambergs (1886-1960), Viktors Eglītis (1877-1945), and Juris Kosa (1878-1967), literature historian and critic Alfrēds Goba (1889-1972), and composers Jānis Norvilis (1906-1994) and Artūrs Salaks (1891-1984). These cultural figures each provided their own contribution to the reconstruction of Latvian paganism.

The founders and most active Dievturi members hoped to create a theoretical base for Latvian paganism and to renew the ancient Latvian beliefs as a religious system. Brastinš was the most productive ${ }^{11}$, but not the only creator of Dievturi literature. For example, Kosa published a brochure, in which the basic ideas of Dievturi were formulated (Kosa 1940). Labietis magazine (1931-1940), in which other members of the Dievturi movement publicised their ideas, was published. Among the books by Brastinš, Dievturu Cerokslis (Dievturi Catechism) (1931), which is structured according to Martin Luther's Der Kleine Katechismus (Small Catechism), is worthy of particular attention.

In the book's introduction, Brastinš points out that the teachings that he offers are based on folk songs, which express "everything which our people thought about God, Laima and Māra" (Brastinš 1932, p. 9). Just like in a Christian catechism, in his catechism too, Brastinšs offers a brief account of what God is, what a person's fundamental laws or commandments for life are and explains the Credo of his teachings. Furthermore, each chapter opens with two folk songs, respectively, two short quatrains, followed by Brastiňš' interpretation. In this way, Brastinšs' teachings have been developed almost like justifications based on revelations.

Dievturi tried to offer an alternative to Christianity but were unable to escape its influence. In this case, it was mainly the influence of Protestantism. After an examination of available

10 As shown by historical documents, about 200-300 persons attended Dievturi events prior to the Second World War (Politiskās 1939).

11 Brastinšs' most outstanding works: (Brastinšs 1929, 1935, 1936). 
archival documents, evidence has not been found that persons with roots in Catholicism, i.e., from eastern Latvia, which is the territory inhabited by Catholics, were active in the Dievturība movement (Politiskās 1939, p. 18). Whereas, it is quite credible that there may have been some nominal Orthodox believers among the Dievturi, ${ }^{12}$ but this would be an issue worthy of further research.

In maintaining that the teachings which they offered were passed down from ancient times, the Dievturi encountered a problem. The ancient Latvian religion, like other traditional religions of the European people, had not gained a systematized religious form prior to the entry of Christianity into Latvia. The ancient Latvian religion existed and was passed on from generation to generation in the form of tradition. In the 1920s-1930s, Dievturi did not pay a lot of attention to folk traditions in reconstructing the rituals. Evidence of this is found in archival documents, in which the structure of Dievturi religious service svêtrits (morning service) is described: the entry of the choir, the opening address, choir music, poetry, the main speech and choir music. ${ }^{13}$ There is no doubt that this type of scenario is more like a cultural event than a religious service. It is obvious that the Dievturi themselves were aware of this, as composer and prominent music teacher Artūrs Salaks had planned for the construction of a special building, where Dievturi weddings and funerals would be held. Being a musician, he popularized the Latvian folk instrument, the kokle, and this specific instrument was always played at Dieoturi events.

In the view of Gatis Ozolinš, "it is evident that Dievturi groups treat Latvian folklore as the source of their ethnic religion" (Ozolinšs 2013, p. 101). Calling their prayers daudzinājumi (exaltation), Dievturi built them on the base of folklore, respectively, they recited folk songs in place of prayers. The selections of folk songs compiled by Brastinš, Latvju Dieva dziesmas (The Songs to God of the Latvians) (1928), Latvju tikumu dziesmas (The Songs of Virtue of the Latvians) (1929) and Latvju gadskārtu dziesmas (The Seasonal Songs of the Latvians) (1929) performed the function of sacral text. In this way, the invention of tradition took place by making folklore materials sacred and at the same time, emphasizing the ethical principles in folk songs.

Dievturi also constructed a special iconography. Artist Jēkabs Bīne, who was the closest confrere of the group leader Brastinšs, researched the symbolism of Latvian signs. In evaluating his work, it should be admitted that Bīne was not an original researcher, as his ideas did not breach "the canon" boundaries marked down in Brastin's' work Latvju rakstu kompozīcija (Composition of Latvian Signs) (1925). However, Bīne's activities made a substantial contribution to popularizing the Dievturi concept. His painting Dievs, Mãra, Laima ${ }^{14}$ (1931) is the most striking example of Dievturi iconography. ${ }^{15}$ It clearly shows that Dievturi perceived the Divine as both masculine and feminine. However, the masculine was the most dominant: in the Dievs-Māra-Laima trinity, the feminine deities (Māra and Laima) were subordinated to the masculine Dievs (God).

In highlighting the indigeneity of reconstructed paganism, Dievturi considered that Latvians were the chosen people, and that it had a special mission: "Dievturiba contains within it, the very best that has been created by the Aryans which has existed from very ancient times until today. God has made Latvians preserve this religion, to teach the wisdom to other Aryan peoples at the time that foreign Christian teaching eventually comes to an end" (Brastinš 1932, p. 11). The ethnic link and continuity between the ancient inhabitants of Latvia and Dievturi were emphasized in this way. One can agree completely that reconstructionist groups "emphasize ethnic connections with a particular place and people and are often feared by other Pagans, rightly or wrongly, to be politically right-wing" (Rountree 2015, p. 16). Latvia's Dievturi accurately correspond to this description, as through the

12 In the late 19th century, a number of Latvians converted to Orthodoxy, adopting the Tsar's religion for economic reasons.

13 For a more detailed analysis of Dievturi religious services, see (Stasulane 2013a).

14 Jēkabs Bīne's painting Māra, Dievs un Laima (1931) is on display at the Latvian National Museum of Art's permanent exposition, and it can be easily found on the internet as well.

15 For more about the Dievturi iconography created by Bīne, see (Ogle 2013, pp. 57-59). 
offering of the Latvian national religion, they fitted in with the early 20th century nationalist politics in Europe.

\section{Indigenous Traditions as an Element of Political Resistance}

After the entry of the USSR's (Union of Soviet Socialist Republics) forces into Latvia (1940) and the introduction of the Soviet regime, the most active Dievturi were subject to repression. ${ }^{16}$ Right up until the death of Stalin, the USSR continued on the path of growing centralization in all areas of life, and "it is understandable that after the suppression of national culture and the persecution of the people, increasing interest developed about national culture in general during the Stalinist period and particularly about those elements, which can strengthen the will of the people to survive" (Biezais 1992, p. 48). In the post-war years, the attempts of the official powers to get people involved in various amateur collectives was expressed quite strongly, and folk dancing groups were formed as a result. Professionals were invited, who could adapt folk songs and dances for stage performances (Cf. Klotinš 2007; Muktupāvels 2007). Ethnographic ensembles operated in a similar way, creating so-called ethnographic performances (Muktupāvels 2007, p. 94). However, the communists monitored the choir and folk dancing groups, particularly modern song and dance groups with the goal of restricting young people from following western cultural trends.

In the 1970s, when the broader society began to find out about its heritage of traditions, the folklore groups brought together like-minded people. The folklore movement developed, focussing its attention on folklore heritage, its reclamation, inheritance and interpretation. Without doubt, information from countries outside of Latvia also had its influence: large-scale ethno-music festivals were organized behind the Iron Curtain. The new ideas inspired ethno-musicologists in Latvia as well, but the Soviet politicians who were involved in culture called ethno-music primitive and amateurish.

The Soviet regime did not permit the existence of uncontrolled organizations within it, which is why the folklore movement was forced to adopt the forms allowed by this political system. Folklore ensembles were established, which began to be called folklore groups in the early 1980s. Folklore groups already attempted to dissociate themselves from stage collectives from the beginnings of the folklore movement, emphasizing their differing nature. The folklore movement became a type of sub-culture, which differed with their diverse behaviour, language and interpretation of folklore. Participants in the folklore groups invited people to get involved in the preservation and cultivation of cultural heritage, for example, to collect the songs and beliefs of the areas from whence they came, to keep ancient customs, make musical instruments etc.

The renewal of traditions turned out to have unbelievably great power: the first folklore festival called Baltica"17 took place in Latvia in 1988, strengthening the Independence movement or the so-called Singing Revolution. That folklore groups became involved in the political movement in the Baltics is extremely significant. In Lithuania, the leading role was played by Sadauja, which Emilija Zaukaitè-Kuzavinienè, who had returned from exile in Siberia, had begun to lead in the late 1960s. This was a folklore group which operated in defiance of Soviet ideology. In Latvia, a similar role was played by Skandinieki, with others following its example.

Andris Slapinš̌́ documentary Latvišu folklore: Gadskārtu dziesmas (Latvia Folklore: Anniversary Songs) (1983), which reflected the activities of participants in the Savieši ('our own people') folklore group over the course of a year, was a significant stimulus for the renewal of traditions. The romantic film showed untouched Latvian natural landscapes and the celebration of annual customs, as if it was beyond time, respectively, in the way that celebrations were conducted in ancient times. The majority of these traditions were not practiced in Soviet Latvia-they had either been transformed with the

16 For more information about this, see (Stasulane and Ozolinš 2017, pp. 238-41).

17 The Baltica international festival demonstrated traditional forms of culture with ethnographic ensembles, folklore groups, folk music groups, storytellers etc. taking part in it. 
changing times or been forgotten. It is important that the director had tried to create an impression of authenticity. The principles of authenticity were observed in the selecting folklore materials and the keeping in line of the film's plot with the instructions of researchers about the celebration of traditions. In the 1980s, there were attempts to revive ancient Latvian traditions among the folklore groups, including religious rituals as well. It is understandable that these were fertile grounds for the revival of Dievturība, and the Dievturi movement gradually recommenced in the late 1980s. It was officially registered as a religious organization in 1990.

\section{Between Local and Global}

Nowadays, paganism in Latvia is represented by several pagan groups, of which eight have joined together in the Community of Latvian Dievturi (Latvijas Dievturu Sadraudze), but some are the so-called independent groups, whose activities are not even registered. In describing contemporary Dievturi groups, their heterogeneous composition needs to be emphasized: "In one congregation, there are those who believe to the letter, everything that Brastinš wrote and created. There are those who had been fervent Christians and now want to be Dievturi Christians. There are free-thinking artists who do not want to be registered anywhere, but who like traditional values, and there are those congregation members who like to sing" (Raups). However, Dievturi also have a common feature, which can be considered a universal feature of contemporary pagans-they are "mainly urbanized literate people who have long ago lost their links with traditional peasant culture, commonly considered the last fortress of pre-Christian beliefs" (Shnirelman 2002, p. 197).

Dievturi consider that they represent ethnic religion, which is the spiritual foundation of the people and a part of the non-material cultural heritage. That the UNESCO Convention for the Safeguarding of Intangible Cultural Heritage (2006) also protects ethnic religions, their belonging to a specific land, people, language, world view and tradition, has been emphasized. At the same time, public regret has been expressed by Dievturi that the Faculty of Theology at the University of Latvia has still not introduced a study course on the most ancient philosophy of God, i.e., Dievturîba (Cf. Kokareviča 2012). There have been attempts to introduce Dievturība as a subject to be taught in schools. As this has not been successful, the Austra group submitted a constitutional grievance, in which the compliance of the Law on Religious Organizations to the Latvian Constitution (Satversme) was disputed. Those submitting the grievance objected that state and local government schools can teach only Christian religious education, in this way creating an advantage for Christian believers and restricting the rights of people whose faith corresponds to the Latvian religion-Dievturiba. The court proceedings were concluded with a non-appealable decision: that the Law on Religious Organizations corresponds to the Latvian Constitution (Latvijas Republikas Satversmes tiesas lēmums 2002).

Prior to the visit of Pope Francis to the Baltic states (2018), the Community of Latvian Dievturi and the Lithuanian group Romuva turned to him with a joint letter of greeting, at the same time inviting him to support the recognition of the ancient Baltic religions at a national level. The letter expressed the hope that, bearing in mind the history of the Baltic peoples and the contemporary understanding of human rights, that the Pope would facilitate Christian tolerance and the recognition of the equal rights of the Baltic religions (Lukjanovs 2018).

The chairman of the board of the Community of Latvian Dievturi is Andrejs Broks, whose confrere Ivo Rubīns is also active in the Latvian Nationalist Club. A connection with politics can continue to be observed in the activities of the Dievturi in this way. As explained by Rubins, the torch procession from the Brethren Cemetery to the Freedom Monument on 11th November, in collaboration with the Vilki (Wolves) folklore group, is becoming increasingly more popular (Kokareviča 2012). On 11th November, the victory in defending Rīga in the Battles for Independence (1919) is commemorated in Latvia, (1919), but the Dievturi group is connecting commemorative day for fallen soldiers with the ancient Latvian traditional religion's departed ancestors' (veli) cult.

The latest trend-nowadays Dievturība is being consolidated not as a religious organization, but as a lifestyle of Latvians, due to the activities of artisans: "Our representatives are being invited more and more 
often to various lecturers and seminars, and we can conclude that a lot of people have come to the conclusion about a Latvian lifestyle, not through Dievturiba, but through their professional activities. For example, pirtnieki [sauna masters] have found out that many things have been said in a specific way about the pirts [sauna] in folk songs" (Kokareviča 2012). The authentic ancient Latvian lifestyle is being reconstructed through turning to folklore as a reference source. Ethnographic heritage is being activated to develop rural tourism and attract foreign travellers. Dievturi consider themselves to be experts on this, and actively provide consultations to businesses which "need an understanding about their identity, and they can go out into the world with it and even earn money" (Kokareviča 2012).

Dievturiba is trying to go beyond the boundaries of the group, as broad collaboration networks are being developed. In 2012, the Zaltis (Adder) Latvian Life Wisdom Centre was established. It is an association which includes the Community of Latvian Dievturi, the Folklore Association, the Folklore Information Centre, the Lauku pirtnieki Association and other organizations, the aim of which is to reconstruct Latvian traditions. Meanwhile the Baltu krivule ${ }^{18}$ (Baltic Gathering) is an annual meeting of the Baltic pagan groups, in which guests from Slavic countries like Poland and Byelorussia also participate. The need to remain faithful to indigenous values, which can ensure the survival of the nation in circumstances of globalization was highlighted during the event. The motive for this event about the exchange of ideas and maintenance of traditions is: the Baltic peoples are united by their living space-the Baltic Sea and lands, the common history and closeness of the culture, deities and traditions. To the question about what is unique, one-off and absolutely original about the Latvians, the Dievturi respond-with the ancient Baltic culture, which continues to be maintained by folklore groups, and the ancient religion, which is expressed in folk songs.

The National Alliance's City of Jūrmala branch's home page offers a Latvian ancient religion renewal project. Its leader, Modris Slava explains that the "Latvian religion has almost been preserved the best out of the European first nations' pre-Christian religion" (Slava 2017). It is surprising that, in offering to restore the ancient religion, criticism has been focussed against Brastinš, who has not understood the essence of the religion and through Dievturîba has provided "materialistic and limited reconstructions" (Slava 2017). The idea of the project is to create a centre of Latvian traditional culture and religion, which would coordinate organizations and groups, which research and practice Latvian traditional culture. Firstly, this means folklore researchers and the leaders of folklore groups. It should be explained that the author of the idea for the project is a populariser of esotericism ${ }^{19}$, and in his view, "the former remains of high religion" can be found in folklore (Slava 2017). According to his plan, Latvians should return to the so-called original religion, which has overgrown with unnecessary layers with the passing of thousands of years, although its elements have been preserved in various religions. In his opinion, "the essence of religion is not some kinds of specific rituals, nor even some kinds of specific teachings, but quite simply the road back to the Divine, to God, which is like a return to the home of one's birth after a journey into the world. This road can be travelled, and is also travelled by any person, whether he/she belongs to some external religion, or not, as the religious road is an internal road, and it takes place within a person, not in churches or temples, and it is of no concern to what the person belongs or does not belong in their outside life" (Slava 2017).

Dievturi consider not just the group members of the movement founded by Ernests Brastins as their own, but also folklorists and all of those, to whom the ancient Latvian religious tradition is close, who gain enlightenment and support in it in their daily life. Contemporary members of the Dievturi movement emphasize that Dievturïba is a renewal of the Latvian world-view interwoven in folk songs, as the main source of Latvia's pagan theoretical interpretation continues to be folklore, especially folk songs, but religious practice is being created, based on evidence of the Latvian traditional lifestyle, mainly through ethnographic descriptions. Despite the references to Latvian folklore and ethnography,

18 Krivule (in Latvian)-'gathering', but the krivulis was the ancient tribe's priest's krivos, the mace or staff of office.

19 The powerful influence of Theosophy, which was established by Helena Blavatsky, exists in Latvia, especially in its new version which was offered by Nicholas Roerich (see Stasulane 2013b). 
the movement's leaders offer creative interpretations. However, even in searching for new and more modern ways of expression, contemporary pagans in Latvia still adopt uncritically Dievturi ideas which were created in the 1920s-1930s and derive their tradition from the theories of the movement's founder.

Currently, a tendency to seek new ideas for the development and popularization of pagan ideas has appeared, which is why the movement is characterized by the entry of creative ideas which are expressed as a rediscovery of "culturally and historically significant objects, including 'Pagan' cultic places" (Muktupāvela 2013, p. 69). The phenomena of new sacred places flourished in Latvia in the late 1980s and the early 1990s, at the moment when Latvia regained its independence, which encouraged searches for Latvian identity, and also when the official atheism was rapidly replaced by religious pluralism. Lokstene Shrine, which is the first Dievturi sacred building in Latvia was built in 2017 on an island on Latvia's largest river, the Daugava. Believing that the state should support this, the Community of Latvian Dievturi requested financial support from the Ministry of Culture (Cf. Liepina 2017). Other people from Lithuania who practice the ancient Baltic religions, as well as several other folklore groups, also participated in the opening of the shrine along with Latvian Dievturi and exile Dievturi representatives (Cf. Uz salas Daugavā atklāta dievturu svētnīca 2017).

A more widely known Latvian sacred site is Pokaini, which is located in the Zemgale region not far from the City of Dobele. Pokaini Forest has become famous with its piles of stones: the concentration of stones of various sizes and forms in one place make many people sense peculiar currents of energy: some see visions, but others perceive a flow of information. ${ }^{20}$ Pokaini was widely talked about already in the 1930s, although a full-fledged discovery of the place did not occur until the 1990s. In 1996, Ivars Vīks ${ }^{21}$ told journalists about strange anomalies and the mysterious features of stones. The information brought up a multitude of discussions and Pokaini forest became a place of pilgrimage for many tourists attracted by rumours about the healing power of this place. ${ }^{22}$ A number of implausible explanations and bizarre assumptions have been created about the stones at Pokaini, ${ }^{23}$ and the guides talk about anomalous natural phenomena that have been observed, but New Age type spiritual mentors and healers consider Pokaini to be the "ancient Latvian civilization's sacred centre" (Kas ir Pokaini?). The Pokaini Forest's Valley of Spirits is visited by strange lit-up balls invisible to the naked eye, but appearing on photographs.

Individual Dievturi have been involved in the work of various political parties, but Dievturi, overall as an organization, have not created their own party. The only exception was Ireena Saprovska's Māras zeme, which has participated several times in Latvian parliamentary elections, and last time received $0.54 \%$ votes. In fact, it was one person's party, and 4899 voters cast their ballots for it. Other Dievturi criticized this party after the loss in the elections: "The worst thing is that in the election, in the Māras zeme's programme, Dievturîba rang out as its goal. But in actual fact, Dievturība is a means for preserving what is Latvian in nature" (Sprūde 2006).

Just like in the early 20th century, today too, Dievturība is characterized by a powerful ethnic dimension. However, Latvians as the chosen ethnicity is not highlighted now, as the view is that each ethnicity has its land, language and traditions. Highlighting tolerance towards the cultural values of all ethnicities and the peaceful co-existence of various peoples, participants in Dievturi groups express an important point of view for Latvian society. However, the concept of being Latvian is an important concept, and all Dievturi activities are subordinated to this: rituals, cultural historical excursions,

20 A local historian Jānis Graudonis believes that the stones were brought by peasants who removed them from their fields. Another theory says that the stones were brought to Pokaini for construction of a castle that was never built.

21 Ivars Vìks (1933-2002)—engineer, metalworking specialist, published articles and books about fortune-telling, the esoteric features of water and the sacred Baltic tribal site at Pokaini. He collaborated with the Baltais aplis New Age group.

22 The stones are considered to have healing properties: some cure joint diseases, some cure osteochondrosis, and other cure gynecological diseases. There are also "dangerous" stones that cause negative consequences if touched.

23 It is voiced that Pokaini was a meeting place of thirty druids, where each druid controlled the weather from his own hill. Another legend says that some strange object is hidden under one of the rocks. Some say it is a radioactive meteorite; some are convinced it is an ancient tomb. The rocks on the hill called Zikkurat face the four parts of the world. It looks like the rocks used to serve as a compass. (See Troitsina). 
tidying up working bees at sacred sites, folklore events, publications in the press, interviews in the media, summer thematic camps, and the celebration of Latvian national celebrations and significant commemorative days.

In the latest research conducted in Latvia, it has been concluded that adherents of Latvian paganism are more religiously and patriotically inclined than Christians and the majority consider that Latvia should be more Latvian (Nastevičs 2018, p. 149). Paganism in Latvia in the near future is dependent on its capacity to respond to the challenges of the era, but, in predicting the more distant future, one comes to express doubts about the Dievturiba as a phenomenon that is capable of surviving. Dievturi in Latvia already currently exist on the periphery of life in society and providing vitally important answers only to the movement's participants, the numbers of which have never exceeded a thousand people, and in fact, we can talk about only a few hundred Dievturi.

Today's paganism movement in Latvia is characterized by contradictory aspects: on the one hand, there is the desire in the activities of the pagans to contrast themselves and their ethnic view against globalization tendencies, which do not conform to traditional culture's unhurried and meditative lifestyle. On the other hand, the processes, which can be observed in contemporary Dievturi groups in Latvia, provide evidence that the form of reconstructed paganism in Latvia falls within the trend of the new spiritual ecology which has come about under the influence of the globalization process (Kale 2004, p. 102). The newest tendencies show that in Latvia too, paganism follows a similar trajectory as Anglo-American paganism, respectively, it is gaining New Age features: esoteric terminology and a self-reflexive nature is also entering pagan discourse.

Funding: This research received no external funding.

Conflicts of Interest: The author declares no conflict of interest.

\section{References}

Biezais, Haralds. 1955. Die Hauptgöttinen der alten Letten. Uppsala: Almqvist \& Wiksell.

Biezais, Haralds. 1961. Die Gottesgestalt der lettischen Volksreligion. Uppsala: Almqvist \& Wiksell.

Biezais, Haralds. 1972. Die himmlische Götterfamilie der alten Letten. Uppsala: Almqvist \& Wiksell.

Biezais, Haralds. 1992. Dievturi-nacionālie romantiḳi-senlatvieši. Celš 1: 43-60.

Brastiňs, Ernests. 1929. Latvju tikumu dziesmas. Rīga: Latvju dievturu draudze.

Brastinšs, Ernests. 1932. Dievturu Cerokslis jeb Teoforu Katkisms tas ir senlatviešu dievestības apcerējums. Rīga: Grāmatu Draugs.

Brastinš, Ernests. 1935. Latviskas Latvijas labad: Mājieni un aicinājumi 1925-1935. Rīga: Zemnieka domas.

Brastiňš, Ernests. 1936. Tautības mācība. Rīga: Zemnieka domas.

Brastinš, Ernests, and Kārlis Bregžis. 1925. Latviešu dievturības atjaunojums: Šaurs vēstures, gudrības un daudzinājuma apraksts. Rīga: Zemnieka domas.

Davy, Barbara Jane. 2007. Introduction to Pagan Studies. Lanham, New York, Toronto and Plymouth: Rowman \& Littlefield Publishers.

Doyle White, Ethan. 2016. Wicca: History, Belief, and Community in Modern Pagan Witchcraft. Toronto: Sussex Academic Press.

Fotoreportāža. 2018. Fotoreportāža: Brīvadabas muzeja gadatirgu apmeklējuši 36300 cilvēku. skaties.lv. Available online: https:/ / skaties.lv/zinas/latvija/fotoreportaza-tukstosiem-lauzu-apmekle-brivdabasmuzeja-gadatirgu/ (accessed on 23 January 2019).

Kale, Sudhir H. 2004. Spirituality, Religion and Globalization. Journal of Macromarketing 24: 92-107. [CrossRef]

Kas ir Pokaini? n.a. dv.lv. Available online: http:/ / www.dv.lv/Tasis/dziednica.html (accessed on 23 January 2019).

Klotiňš, Arnolds. 2007. Atskats folkloras kustībā. Letonica 17: 95-122.

Kokareviča, Dace. 2012. Celabiedros ar dievturiem. Latvijas Avīze. Available online: http:/ /www.la.lv/celabiedrosar-dievturiem-\%E2\%80\%A9-3 (accessed on 23 January 2019).

Kosa, Juris. 1940. Latviskā dievzina: Dievturības pamatmācība. Rīga: Labietis.

Latvijas Dievturu Sadraudze. n.a. Available online: http:/ / dievturi.blogspot.com/p/par-mums.html (accessed on 23 January 2019). 
Latvijas Republikas Saeima. n.a. Available online: http:/ /www.saeima.lv/lv/par-saeimu/likumdeveju-vesture (accessed on 13 March 2019).

Latvijas Republikas Satversmes tiesas lēmums. 2002. Likumi.lv. Available online: https://m.likumi.lv/doc.php? $\mathrm{id}=68351$ (accessed on 23 January 2019).

Liepina, Anita. 2017. Latvijas Dievturu Sadraudzes vieta Latvijā. Jaunā Gaita. Available online: https:/ /jaunagaita. net/jg290/JG290_Liepina.htm (accessed on 23 January 2019).

Lukjanovs, Igors. 2018. Latvijas Dievturu sadraudze un Lietuvas kopiena Romuva aicina pāvestu palīdzēt panākt senās baltu ticības valstisku atzīšanu. protesti.lv. Available online: http: / / www.protesti.lv / latvijas-dievturu-sadraudze-un-lietuvas-kopiena-romuva-aicina-pavestupalidzet-panakt-senas-baltu-ticibas-valstisku-atzisanu/ (accessed on 23 January 2019).

Misāne, Agita. 2005. Dievturība Latvijas reliǵisko un politisko ideju vēsturē. Reliǵiski-filozofiski raksti 10: 101-17.

Muktupāvela, Rūta. 2013. The Mythology of Ethnic Identity and the Establishing of Modern Holy Places in Post-Soviet Latvia. Pomegranate: The International Journal of Pagan Studies 14: 69-90. [CrossRef]

Muktupāvels, Valdis. 2007. Varas un pētniecības valoda, zīmes un simboli 20. gs. 80. gadu folklorisma mūzikā un muzicēšanā. In Kultūra un vara: Raksti par valodu, literatūuru, tradicionālo kultūuru. Edited by Kursīte Janīna and Jolanta Strauga. R̄̄ga: LU Akadēmiskais apgāds, pp. 92-102.

Nastevičs, Uǵis. 2018. Reliǵiskā identitāte un tikumi: aktualitāte audzināšanā Latvijā. Latvijas Universitātes Raksti 816: $142-50$.

Ogle, Kristīne. 2013. Representation of Nature Spirits and Gods in Latvian Art in the First Half of Twentieth Century. Pomegranate: The International Journal of Pagan Studies 14: 47-68. [CrossRef]

Ozolinš, Gatis. 2013. The Dievturi Movement in Latvia as Invention of Tradition. In Modern Pagan and Native Faith Movements in Central and Eastern Europe. Edited by Kaarina Aitamurto and Scott Simpson. Durham: Acumen, pp. 94-112.

Paeglis, Armands. 2005. Pērkonkrusts pār Latviju 1932-1940. Rīga: Klubs, p. 415.

Politiskās. 1939. Politiskās policijas pārvaldes Rīgas rajona kartotēkas uzzina. August 21, Box 3235, Folder 1/1: 597.1. Rīga: Latvian State Historical Archives.

Priede, Jānis. 2015. Development of the Study of Religion in Latvia in the 20th century. In Studying Religions with the Iron Curtain Closed and Opened. Edited by Tomas Bubik and Henryk Hoffmann. Leiden and Boston: Brill, pp. 199-238.

Raups, Edvīns. n.a. Katram latvietim savs dievs. folklora.lv. Available online: http://folklora.lv/vestkopas/ folkloristi/delis.cgi?read=1181 (accessed on 23 January 2019).

Rountree, Kathryn. 2015. Context is Everything: Plurality and Paradox in Contemporary European Paganisms. In Contemporary Pagan and Native Faith Movements in Europe: Colonialist and Nationalist Impulses. Edited by Kathryn Rountree. New York and Oxford: Berghahn, pp. 1-24.

Rydgren, Jens. 2005. Is Extreme Right-Wing Populism Contagious? Explaining the Emergence of a New Party Family. European Journal of Political Research 44: 413-37. [CrossRef]

Saunders, Robert A. 2013. Pagan Places: Towards a Religio-geography of Neopaganism. Progress in Human Geography 37: 786-810. [CrossRef]

Shnirelman, Victor A. 2002. "Christians! Go home": A Revival of Neo-Paganism between the Baltic Sea and Transcaucasia. Journal of Contemporary Religion 17: 197-211. [CrossRef]

Slava, Modris. 2017. Latviešu senās religijas atjaunošanas projekts. Nacionālā apvienūba: Jūrmalas nodala. Available online: https: / / www.nacionalaapvieniba.lv / nodalu_raksti/latviesu-senas-religijas-atjaunosanas-projekts / (accessed on 23 January 2019).

Sprūde, Viesturs. 2006. Dievturi Gatavi Ilgai Cīnai. Latvijas Avīze. Available online: https://www.astrologi.lv / sakums/raksti/57/Ezoterika/Dievturi-gatavi-ilgai-cinai/ (accessed on 23 January 2019).

Stasulane, Anita. 2013a. The Dievturi Movement in the Reports of the Latvian Political Police. Pomegranate: The International Journal of Pagan Studies 14: 31-46. [CrossRef]

Stasulane, Anita. 2013b. Theosophy of the Roerichs: Agni Yoga or Living Ethics. In Handbook of the Theosophical Current. Edited by Olav Hammer and Michael Rothstein. Leiden and Boston: Brill, pp. 193-216.

Stasulane, Anita, and Gatis Ozolinšs. 2017. Transformations of Neopaganism in Latvia: From Survival to Revival. Open Theology 2: 235-48. [CrossRef]

Švābe, Arveds, ed. 1950. Latvju enciklopēdija. Stokholma: Apgāds Trīs zvaigznes, vol. 1. 
Švābe, Arveds, Aleksandrs Būmanis, and Kārlis Dišlērs, eds. 1933. Latviešu konversācijas vārdnīca. Rīga: A.Gulbja apgādībā, vol. 10 .

Troitsina, Magarita. n.a. World's Strongest Anomalous Zone Produces Inexplicable for NASA Radiation. pravda.ru. Available online: http:/ / english.pravda.ru/society/anomal/21-10-2009/110030-pokaini_forest0/ (accessed on 23 January 2019).

Uz salas Daugavā atklāta dievturu svētnīca. 2017. skaties.lv. Available online: https://skaties.lv/zinas/latvija / sabiedriba/uz-salas-daugava-atklata-dievturu-svetnica/ (accessed on 23 January 2019). 